\title{
MUTU IKAN KAKAP MERAH YANG DIOLAH DENGAN PERBEDAAN KONSENTRASI LARUTAN GARAM DAN LAMA PENGERINGAN
}

\section{(Red snapper quality cooked with different salt solution concentration and old dried)}

\author{
Albert R. Reo ${ }^{1}$ \\ ${ }^{1}$ Fakultas Perikanan dan Ilmu Kelautan, Universitas Sam Ratulangi, Manado, Sulawesi Utara.
}

\begin{abstract}
Ikan adalah salah satu sumber protein hewani yang tinggi (18-20\%)untuk memenuhi nutrisi dan kesehatan yang baik untuk tubuh manusia. Tujuan dari penelitian ini adalah untuk mengetahui kadar air, lemak dan protein, serta mengetahui preferensi panelis level untuk ikan kakap merah asin. Hasil analisis kaddr air produk dengan konsentrasi larutan garam 15\% pengeringan 12 jam adalah 37,38\% juga konsentrasi larutan garam 17\% dengan pengeringan 12 jam adalah 33,71\%. Itu berarti memiliki nilai kadar air dapat diterima dan memiliki kualitas yang baik. Hasil kadar protein produk kakap merah asin konsentrasi larutan garem $15 \%$ dengan pengeringan 8 jam si 17\% dengan pengeringan 10 jam adalah 39,73\% memiliki nilai kadar protein dapat diterima dan memiliki kualitas yang baik. Hasil uji organoleptik seperti tekstur, oder, preferensidąn konsentrasi memiliki nilai tinggi dengan konsentrasi larutan garam 15-17\%, pengeringan 12 jam
\end{abstract}

Kata kunci: kakap merah, konsentrasi larutan garam, waktu pengeringan.

Fish is the one of animal protein it means have a importance in hutrition and health. Fish also one the resource animal protein most as a food. Fish have a high protein content is around $18-20 \%$, that is why good for human body. The objective of this research is to know the water content, fat, protein and know the level preference panelis to the salted fish red snapper. The result of water content analysis product with concentration salted solution $15 \%$ with during 12 hours is $37,38 \%$ also concentration salted solution $17 \%$ with drying 12 hours is $33,71 \%$. That means have water content value can accepted and have a good quality. The result of protein content the product red snapper salted concentration solution $15 \%$ with drying 8 hours si $17 \%$ with drying 10 hours is $39,73 \%$ have a protein content value can accepted and have a good quality. The result of organoleptic test like texture, oder, preference and concentration the average score have a highest value which the concentration $15-17 \%$ salted solution with drying 12 hours because for that treatment organoleptic mostly pandis like it.

Keywords: red snapper, salt concentration, drying time.

$$
\text { PENDAHULUAN }
$$

Ikan merupakan bahan pangan yang mudah rusak/membusuk. Baru hanyatdalám waktu sekitar 8 jam sejak ikan ditangkap dan didaratkan sudah akan timbul proses perubahan yang mengarah pada proses kerusakan. Karena itu agar ikan dan hasil perikanan lainnyar dapat dimanfaatkan secara maksimal mungkin perlu dijaga kondisinya. Pengolahan merupakan sâlah satu cara untuk mempertahankan ikan darrproses pembusukan sehingga mampu disimpan lama sampai tiba waktunya untuk dijadikan sebagai bahan konsumsi (Adawyah, 2008).

Ikan merupakan sumber makanan yang sangat penting bagi manusia karena mengandung protein yang tinggi yaitu berkisar antara $18-20 \%$ sehingga sangat baik bagi tubuh manusia dan relatif murah harganya, sehingga ikan menjadi komoditas yang penting (Anonimous, 2003). Salah satu jenis ikan yang mempunyai prospek baik dan juga dapat diangkat sebagai salah satu komoditi hasil perikanan yang mempunyai nilai ekonomis penting adalah ikan kakap merah (red snapper/Lutjanus sp.). Ikan ini dapat dibuat berbagai masakan, salah satunya adalah ikan asin.

Masalah yang dihadapi pada penanganan ikan adalah cepat menjadi busuk yaitu beberapa jam setelah penangkapan. menyatakan bahwa banyak faktor yang menentukan kecepatan penurunan kesegaran ikan terutama suhu penyimpanan (Suwetja, 2013). Begitu pula halnya dengan ikan kakap merah memerlukan proses penanganan yang baik. Untuk itu perlu dilakukan pengawetan segera mungkin. Moeljanto (1992) menyatakan bahwa pengawetan dan pengolahan bahan pangan bertujuan untuk menghambat atau menghentikan kegiatan enzim atau mikroorganisme yang dapat menimbulkan pembusukan dan memberikan sifat fisikawi dan organoleptik yang khas. Keadaan ini dapat diatasi dengan beberapa cara pengolahan dan pengawetan antara lain berupa pemberian bahan pengawet dan pengeringan.

Pengeringan adalah salah satu cara untuk mengeluarkan atau menghilangkan sebagian besar 
air dari suatu bahan pangan dengan menggunakan energi panas. Biasanya kandungan air bahan dikurangi sampai batas tertentu hingga mikroba tidak dapat tumbuh pada bahan tersebut (Muthadi dan Ayustaningwarno, 2010). Penggaraman dan pengeringan merupakan salah satu cara pengolahan tradisional hasil perikanan yang mempunyai peranan penting baik dalam usaha maupun upaya pemenuhan gizi protein. Pengawetan ikan dengan cara penggaraman sebenarnya terdiri dari dua proses, yaitu proses penggaraman dan pengeringan. Adapun tujuan utama dari penggaraman yaitu untuk memperpanjang daya tahan dan daya simpan ikan. Ikan yang mengalami proses penggaraman menjadi awet karena garam dapat menghambat atau membunuh bakteri penyebab pembusukan pada ikan. Hasil akhir dari pengawetan dengan proses penggaraman adalah ikan asin. Salah satu penyebab mengapa kurangnya orang mengkonsumsi ikan asin dalam jumlah yang banyak yaitu terlalu banyaknya jumlah konsentrasi garam yang diberikan pada produk ikan asin tersebut sehingga ikan terasa sangat asin dan terasa tidak enak di lidah bila mengkonsumsinya terlalu banyak.

Dengan konsentrasi larutan garam dan lama pengeringan yang digunakan dalam pembuatan ikan asin diduga dapat mempengaruhi mutu dan penerimaan panelis terhadap ikan kakap merah asin. Bertolak dari dugaan tersebut maka penelitian ini bertujuan untuk mengetahui pengaruh konsentrast larutan garam dan lama pengeringan ikan lakap merah terhadap mutu dan penerimaan panelis (berdasarkan penilaian organoleptik).

\section{METODE PENEKTOAN}

Metode eksperimen digunakan dalam penelitian ini untuk menyelidiki kebenaran atau menguji hubungan sebab-akibat diantara variabel yang diteliti dengan cara mengenakan perlakuan dan memperbandingkan hasilnya dengan satu atau lebih kelompok kontrol (Mardalis, 1989). Ikan kakap merah segar yang digunakan berukuran panjang berkisar antafa 10-17 cm dan berat 100-120 gram/ekor, yang digunakan dalam penelitian ini berjumlah 36 ekountuk dua kali ulangan. Ikan dibelah dan dibersihkan. Setelah itu ikan tersebut direndam dalam larutan air garam dengan konsentrasi 13, 15 dan 17\% (perlakuan A). Kemudian ikan dikeringkan dengan variasi waktu pengeringan 8, 10 dan 12 jam (perlakuan B). Setelah itu, dilakukan pengujian kadar air dan kadar lemak mengikuti prosedur dari Sudarmadji, et al. (1997). Pengujian kadar protein mengikuti prosedur yang dikemukakan oleh Afrianto dan Liviawati (1989), serta uji organolep- tik oleh Soekarto (1991). Prosedur penelitian yang lebih jelas dapat dilihat pada Gambar 1. Uji organoleptik meliputi kenampakan, bau, cita rasa, dan konsistensi yang dianalisis dengan menggunakan tabel nilai organoleptik ikan asin kering berdasarkan Standar Nasional Indonesia (SNI) 01-2346-1991 (Anonimous, 1992).

\begin{tabular}{c} 
Ikan kakap merah segar \\
(sebanyak 36 ekor, berat 100-120 gr/ekor) \\
\hline
\end{tabular}



Berdasarkan perlakuan ini, maka data yang diperoleh dianalisis dengan menggunakan Rancangan Acak Lengkap (RAL) yang disusun secara faktorial $3 \times 3$, dengan 2 kali ulangan untuk setiap perlakuan. Untuk melihat tingkat perbedaan dari setiap perlakuan dilakukan uji F. Jika pengaruh yang signifikan terhadap parameter uji maka dilanjutkan dengan uji Beda Nyata Terkecil (BNT) (Steel and Torrie, 1998).

\section{HASIL DAN PEMBAHASAN}

\section{Analisis Kadar Air}

Analisis data kadar air yang diperoleh dari hasil penelitian ini, menunjukkan bahwa nilai ratarata kadar air tertinggi adalah $48,03 \%$ pada konsentrasi larutan garam 13\% dengan lama pengeringan 8 jam sedangkan nilai terendah $33,71 \%$ pada konsentrasi larutan garam $17 \%$ dengan lama pengeringan $12 \mathrm{jam}$. Kualitas ikan asin kering yang ditetapkan menurut SNI memiliki nilai kadar air 40\% (Anonimous, 1992). Nilai ini berarti bahwa produk ikan kakap merah asin yang dihasilkan pada konsentrasi larutan garam 15\% dengan lama pengeringan 12 jam yaitu $37,38 \%$ dan juga terdapat pada konsentrasi larutan garam 17\% dengan lama pengeringan 12 jam yaitu 33,71\% memiliki nilai kadar air yang dapat diterima. 
Nilai rata-rata kadar air ikan kakap merah asin dari berbagai kombinasi perlakuan dapat dilihat pada Gambar 2.

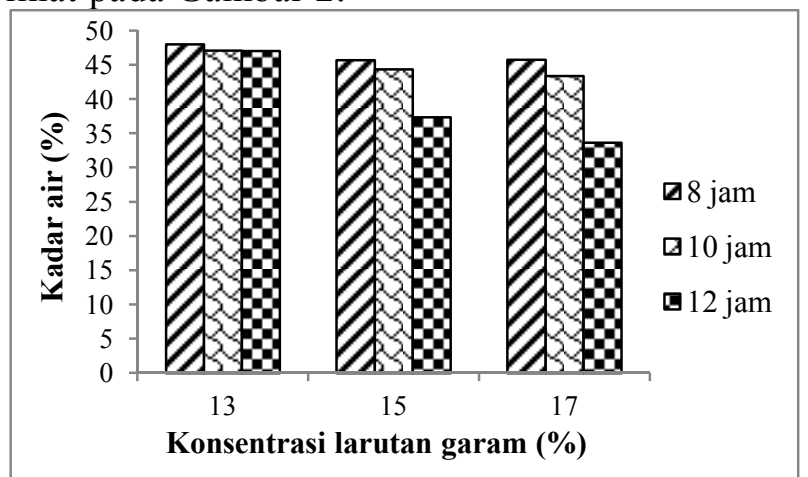

Gambar 2. Nilai rata-rata kadar air pada ikan kakap merah asin.

Figure 2. Mean values of water content at salted fish red snapper.

Nilai kadar air yang diperoleh pada setiap konsentrasi larutan garam dan lama pengeringan mengalami penurunan. Persentase penurunan kadar air tertinggi yang dipengaruhi oleh konsentrasi larutan garam, terjadi pada perlakuan dari konsentrasi larutan garam 13\% (kadar airnya 47,08\%) hingga konsentrasi larutan garam 15\% (37,38\%) dengan lama pengeringan $12 \mathrm{jam}$. Sedangkan persentase penurunan kadar air terendah terjadi pada perlakuan dari konsentrasi larutan garam $15 \%$ (kadar airnya 44,41\%) hingga konsentrasi larutan garam 17\% (kadar airnya 43,42\%) dengan lama ped ngeringan $10 \mathrm{jam}$.

Persentase penurunan kadar aiłtertinggi yang dipengaruhi oleh lama pengeringan terjadi pada perlakuan dari lama pengeringan 10 jam (kadar airnya 43,42\%) hingga lama pengeringan 12 jam (kadar airnya 33,71\%) dengan konsentrasi larutan garam $17 \%$. Sedang persentase penurunan kadar air terendah terjadi pada perlakuan dari lama pengeringan 10 jam (kadăr airnya 47,15\%) hingga lama pengeringan 12 jam (kadar airnya 47,08\%) dengan konsentrasi larutan garam 13\%.

Menurunnya jumlah kadar air secara garis besar dikarenakan selama proses penggaraman berlangs̊ung terjadi penetrasi garam ke dalam tubuh ikandanmengakibatkan cairan dari tubuh ikan keluar, hal ini dikarenakan adanya perbedaan konsentrasi. Menurut Adawyah (2008) garam pada dasarnya tidak bersifat membunuh mikroorganisme tetapi hanya menyerap cairan tubuh ikan berkadar air sedang yaitu berkisar antara $10-40 \%$. Lamanya waktu pengeringan sangat berpengaruh terhadap kadar air bahan, semakin lama waktu pengeringan maka semakin rendah kadar air dari produk ikan tersebut. Jika diperhatikan pada Gambar 2 maka nilai rata-rata kadar air terendah adalah $33,71 \%$.
Tabel 1. Hasil analisis sidik ragam kadar air ikan kakap merah asin.

Table 1. Anova of water content data at salted fish red snapper.

\begin{tabular}{|c|c|c|c|c|c|}
\hline $\begin{array}{c}\text { Sumber } \\
\text { Keragaman }\end{array}$ & db & JK & KT & $\mathbf{F}_{\text {hitung }}$ & $\begin{array}{c}F_{\text {tabel }} \\
0,050,01\end{array}$ \\
\hline Perlakuan & 8 & 23709,97 & 2963,75 & 1287,35 & $3,23 \quad 5,47$ \\
\hline A & 2 & 33,87 & 16,93 & ${ }^{*} 7,36$ & $4,268,02$ \\
\hline B & 2 & 42,41 & 21,2 & ${ }^{* *} 9,21$ & $4,268,02$ \\
\hline AB (interaksi) & 4 & 23633,69 & 5908,42 & ${ }^{*} 2566,42$ & $3,636,42$ \\
\hline Galat & 9 & 20,72 & 2,30 & & \\
\hline Total & 17 & 23730,69 & & & \\
\hline
\end{tabular}

Dari hasil analisis sidik ragam pada Tabel 1, dapat dilihat bahwa perlakuan konsentrasi larutan garam (A) memberikan pengaruh yang berbeda nyata, sedangkan perlakuăn lama pengeringan (B) memberikan pengaruh sangat nyata. Sedangkan interaksi antara konsentrasi larutan garam dan lama pengeringan juga memberi pengaruh yang sangat nyata. Ini berarti da pengaruh konsentrasi larutan garam (A) dan lama pengeringan (B) terhadap jumlah kadar air, sehingga perlu dilakukan uji lanjut ant $\mathrm{k}$ mengetahui perlakuan mana saja yang berbeda nyata. Hal ini menunjukkan hipotesis H1 diterma.

Dari hasil uji BNT dapat diketahui bahwa sebagian besar nilai kadar air pada interaksi kedua perlakuan memberikan hasil yang tidak nyata perbedaannya, kecuali pada interaksi berikut ini yang nyata perbedaannya:

- Konsentrasi $13 \%$ pengeringan 8 jam dengan nilai kadar air pada lama pengeringan 12 jam konsentrasi $17 \%$ dan $15 \%$.

- Konsentrasi $13 \%$ pengeringan 10 jam dengan nilai kadar air pada lama pengeringan 12 jam konsentrasi $17 \%$ dan $15 \%$.

- Konsentrasi 13\% pengeringan 12 jam dengan nilai kadar air pada lama pengeringan 12 jam konsentrasi $17 \%$ dan $15 \%$.

- Konsentrasi 17\% pengeringan 8 jam dengan nilai kadar air pada lama pengeringan 12 jam konsentrasi $17 \%$ dan $15 \%$.

- Konsentrasi $15 \%$ pengeringan 8 jam dengan nilai kadar air pada lama pengeringan 12 jam konsentrasi $17 \%$ dan $15 \%$.

- Konsentrasi $15 \%$ pengeringan 10 jam dengan nilai kadar air pada lama pengeringan 12 jam konsentrasi $17 \%$ dan $15 \%$.

- Konsentrasi $17 \%$ pengeringan 10 jam dengan nilai kadar air pada lama pengeringan 12 jam konsentrasi $17 \%$ dan $15 \%$.

Dengan demikian dapat dikatakan bahwa penambahan konsentrasi larutan garam dan lama pengeringan memberikan pengaruh terhadap penurunan jumlah kadar air. 


\section{Analisis Kadar Lemak}

Nilai rata-rata kadar lemak yang tertinggi adalah $11,03 \%$ yang didapat pada konsentrasi larutan garam $17 \%$ dengan lama pengeringan $10 \mathrm{jam}$ sedangkan kadar lemak terendah adalah 5,46\% yang didapat pada konsentrasi larutan garam 15\% dengan lama pengeringan $8 \mathrm{jam}$. Kualitas ikan asin kering yang ditetapkan menurut SNI yaitu memiliki nilai kadar lemak 10\% (Anonimous, 1992). Ini berarti bahwa produk ikan kakap merah asin yang dihasilkan pada konsentrasi larutan garam 17\% dengan lama pengeringan 12 jam yaitu $9,17 \%$ memiliki nilai kadar lemak yang dapat diterima.

Nilai rata-rata kadar lemak ikan kakap merah dari berbagai kombinasi perlakuan dapat dilihat pada Gambar 3.

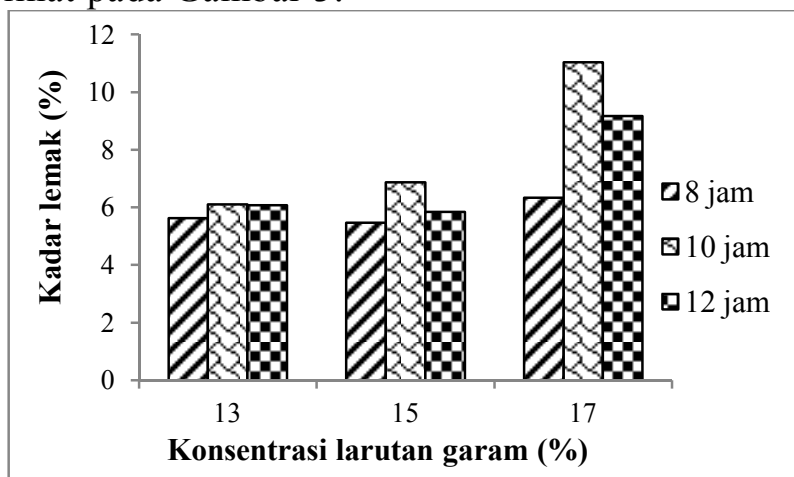

Gambar 3. Nilai rata-rata kadar lemak pada ikan kakap merah asin.

Figure 3. Mean values of fat content at salted fish red snapper.

Nilai kadar lemak yang diperolekppada setiap konsentrasi larutan garam dan lamap pengeringan mengalami peningkatan. Persentase peningkatan kadar lemak tertinggi terjadi pada perlakuan dari konsentrasi larutan garam $15 \%$ (kadar lemaknya $6,87 \%$ ) hingga $17 \%$ (kadar lemaknya $11,03 \%$ ) dengan lama pengeringan $10 \mathrm{jam}$. Sedangkan persentase peningkatankadar lemak terendah terjadi pada perlakuan darikonsentrasi larutan garam 13\% (kadar lemaknya $6,10 \%$ ) hingga 15\% (kadar lemaknya 6,87\%) dengan lama pengeringan $10 \mathrm{jam}$. Kadar lemak pada lama pengeringan antara 8 jam dengạn 10 jam mengalami peningkatan, namun setetah dilakukan pengeringan sampai 12 jam kadar lemák mengalami penurunan. Menurut Juliana (1999), jumlah kadar lemak dalam bahan pangan sangat dipengaruhi oleh suhu dan waktu pemanasan, dimana pemanasan yang dilakukan di atas $55^{\circ} \mathrm{C}$ akan mengakibatkan mencairnya lemak sehingga kadar lemak dalam ikan akan berkurang. Begitu juga dengan waktu pemanasan, dimana semakin lama waktu pemanasan akan semakin banyak lemak yang akan keluar dan menguap. Sedangkan menurut Suwetja (2011), kadar lemak pada ikan juga dipengaruhi oleh umur, ukuran, jenis kelamin, musim dan suhu perairan tempat penangkapan.

Pada Tabel 2, dapat dilihat bahwa perlakuan konsentrasi larutan garam (A) dan lama pengeringan (B) tidak memberi pengaruh yang nyata terhadap kadar lemak. Sedangkan pada interaksi dari kedua perlakuan tersebut memberikan pengaruh sangat nyata, ini menunjukkan bahwa hipotesis $\mathrm{H}_{1}$ diterima. Berarti pada interaksi kedua perlakuan ada yang berpengaruh terhadap nilai kadar lemak ikan kakap merah asin, sehingga pepru dilakukan uji lanjut untuk mengetahui perlakuan mána saja yang berbeda nyata.

Tabel 2. Hasil analisis sidik ragam kadar lemak ikan kakap merah asin.

Table 2. Anova of fat content data at salted fish red snapper.

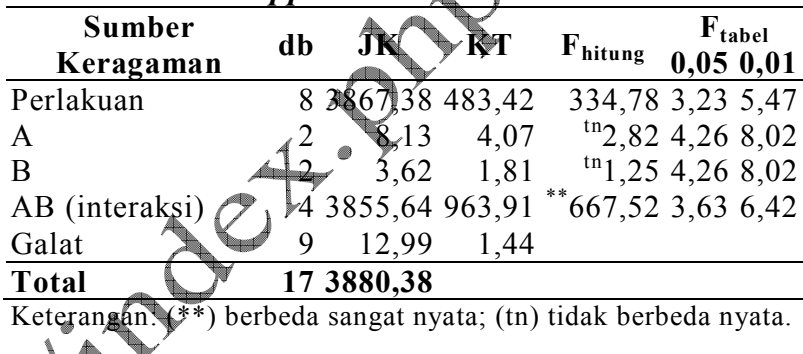

A Dari tabel uji BNT menunjukkan bahwa interaksi kedua perlakuan memberikan hasil yang tiđak nyata perbedaannya, kecuali pada interaksi berikut ini yang berbeda nyata; Konsentrasi 17\% pengeringan 10 jam dengan nilai kadar lemak pada lama pengeringan 8 jam konsentrasi 13\% dan 15\%, serta pada konsentrasi $15 \%$ pengeringan 12 jam. Dengan demikian umumnya kombinasi perlakuan memberikan pengaruh yang tidak nyata.

\section{Analisis Kadar Protein}

Data analisis kadar protein yang diperoleh dari hasil penelitian ini menunjukkan bahwa nilai rata-rata kadar air tertinggi adalah $46,04 \%$ yaitu pada konsentrasi larutan garam 13\% dengan lama pengeringan 12 jam sedangkan nilai rata-rata kadar protein terendah adalah $37,41 \%$ yaitu pada konsentrasi larutan garam 13\% dengan lama pengeringan 8 jam. Kualitas ikan asin kering yang ditetapkan menurut SNI yaitu memiliki nilai kadar protein 40\% (Anonimous, 1992). Ini berarti bahwa produk ikan kakap merah asin yang dihasilkan pada konsentrasi larutan garam $15 \%$ dengan lama pengeringan 8 jam yaitu 39,2\% dan konsentrasi larutan garam $17 \%$ dengan lama pengeringan 10 jam yaitu $39,73 \%$ memiliki nilai kadar protein yang dapat diterima. Nilai rata-rata kadar protein ikan kakap merah asin dari berbagai kombinasi perlakuan dapat dilihat pada Gambar 4. 


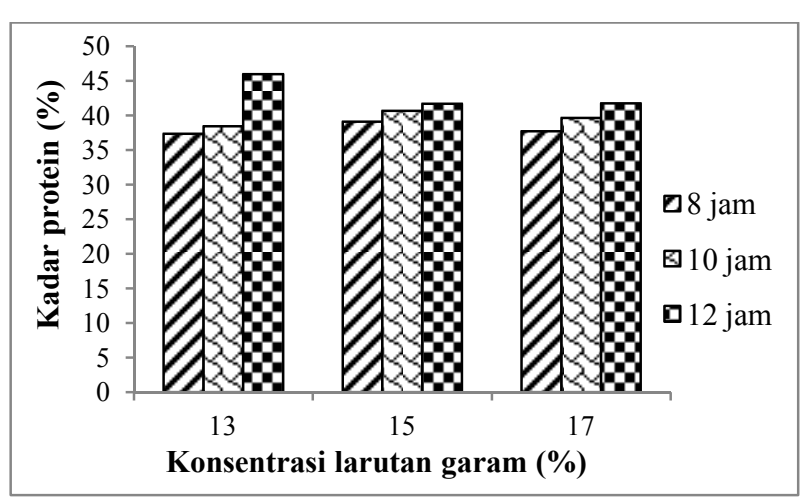

Gambar 4. Histogram nilai rata-rata kadar protein pada ikan kakap merah asin

Figure 4. Mean values of protein content at salted fish red snapper.

Tabel 3. Hasil analisis sidik ragam kadar protein ikan kakap merah asin.

Table 3. Anova of protein content data at salted fish red snapper.

\begin{tabular}{|c|c|c|c|c|c|}
\hline $\begin{array}{c}\text { Sumber } \\
\text { Keragaman }\end{array}$ & db & JK & KT & $F_{\text {hitung }}$ & $\begin{array}{c}F_{\text {tabel }} \\
0,050,01\end{array}$ \\
\hline Perlakuan & 8 & 1383,78 & 2672,97 & 746.45 & $3,235,47$ \\
\hline A & 2 & 0,69 & 0,35 & $0.09^{\text {tn }}$ & $4,268,02$ \\
\hline B & 2 & 20,45 & 10,23 & $2.86^{\operatorname{tn}}$ & $4,268,02$ \\
\hline AB (interaksi) & 4 & 1362,63 & 5340,66 & $1491.43^{\text {** }}$ & $3,636,42$ \\
\hline Galat & 9 & 32,23 & 3,58 & & \\
\hline Total & & 416,01 & & & \\
\hline
\end{tabular}

Nilai kadar protein yang dipengaruhi olehp lama pengeringan mengalami peningkatan. Persentase peningkatan kadar protein tertinggi terjadi pada perlakuan dari lama pengeringan 10 jam (kadar protein $38,5 \%$ ) hingga lama pengeringan $12 \mathrm{jam}$ (kadar protein 46,04\%) dengan konsentrasi 13\%. Sedangkan persentase peningkatan kadar protein terendah terjadi pada perlakuan lama pengeringan 8 jam (kadar protein 37,48\%), hingga lama pengeringan 10 jam (kadar proteinnya 38,5\%) dengan konsentrasi larutan garam 13\%. Peningkatan jumlah kadar protein pada måsing-masing perlakuan disebabkan oleh rendahnya kadar air sehingga kadar protein menfngkat. Makin tinggi konsentrasi larutan garam dan lama pengeringan, maka kadar $\mathrm{NaCl}$ yangterserap ke dalam daging ikan semakin tinggi, sedangkan kadar air semakin menurun mengakibatkan meningkatnya nilai kandungan proteir Hal ini disebabkan oleh garam yang diserap ke dalam daging mendenaturasi larutan protein sehingga terjadi koagulasi yang membebaskan air keluar dari daging ikan. Winarno et al. (1982) mengemukakan bahwa dengan mengurangi kadar air, bahan pangan akan mengandung senyawa-senyawa seperti protein, karbohidrat, lemak dan mineral dalam konsentrasi lebih tinggi.

Pada Tabel 3, dapat dilihat bahwa perlakuan konsentrasi larutan garam (A) dan lama penge- ringan (B) tidak memberi pengaruh yang nyata terhadap kadar protein. Sedangkan pada interaksi dari kedua perlakuan tersebut memberikan pengaruh yang sangat nyata, ini menunjukkan bahwa hipotesis $\mathrm{H}_{1}$ diterima. Berarti pada interaksi kedua perlakuan ada yang berpengaruh terhadap nilai kadar protein ikan kakap merah asin, sehingga perlu dilakukan uji lanjut untuk mengetahui perlakuanperlakuan mana saja yang berbeda nyata.

Dari tabel uji BNT menunjukkan bahwa perlakuan konsentrasi larutan garam dan larna pengeringan memberikan hasil yang tidak thyata perbedaannya, kecuali pada interaksi berikut-inr yang nyata perbedaannya. Konsentrasi $13 \%$ pengeringan 12 jam dengan nilai kadar air pada konsentrasi $13 \%$ pengeringan 8 dan 10 jam, konsentrasi $15 \%$ pengeringan $8 \mathrm{jam}$, dan pada Konsentrasi $17 \%$ pengeringan 8 dan 10 jam Hal in disebabkan karena semakin tinggi konsentrasi larutan garam makin banyak molekul air yang diserap keluar, sehingga menyebabkan kandungan protein meningkat.

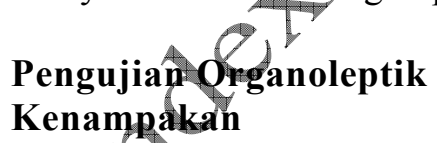

\section{Kenampakan}

Data analisis tingkat kesukaan kenampakan ikan kakap merah asin yang diperoleh dari hasilpenelitian ini menunjukkan bahwa skor ratarata tingkat kesukaan kenampakan yang terendah adalah 5,54 (sedikit rusak fisik, kurang bersih, beberapa bagian berkarat mengarah utuh, kurang bersih agak kusam) yaitu pada perlakuan konsentrasi larutan garam 13\% dengan lama pengeringan 8 jam. Sedangkan skor rata-rata tingkat kesukaan kenampakan yang tertinggi adalah 8,6 (utuh, bersih, kurang rapi, bercahaya menurut jenis). Skor rata-rata tingkat kesukaan kenampakan ikan kakap merah asin dari berbagai kombinasi perlakuan dapat dilihat pada Gambar 5.

Kualitas ikan asin kering yang ditetapkan menurut SNI yaitu memiliki skor rata-rata nilai organoleptik 6,5 (Anonimous, 1992). Ini berarti bahwa produk ikan kakap merah asin yang dihasilkan dari masing-masing kombinasi perlakuan umumnya memiliki nilai organoleptik kenampakan yang dapat diterima atau disukai. Penilaian organoleptik kenampakan produk ikan kakap merah asin dengan skor tertinggi $(8,6)$ yaitu pada perlakuan perbedaan konsentrasi larutan garam 17\% dengan lama pengeringan 12 jam lebih disukai. Sedangkan penilaian organoleptik untuk kenampakan dengan skor terendah $(5,54)$, agak tidak disukai panelis.

Adanya perbedaan kesukaan kenampakan pada produk ikan kakap merah asin dari berbagai 
kombinasi perlakuan, karena adanya penambahan konsentrasi larutan garam. Dengan nilai organoleptik kenampakan meningkat dengan adanya penambahan garam, sehingga dapat menyebabkan denaturasi protein dan dapat mempengaruhi kenampakan daging. Hal ini juga disebabkan oleh adanya proses dehidrasi permukaan daging, sehingga konsentrasi pigmen pada permukaan daging menjadi meningkat. Winarno et al. (1982) pigmen sangat sensitif terhadap pengaruh kimia dan fisik selama pengolahan terutama panas sangat berpengaruh terhadap pigmen bahan pangan.



Gambar 5. Histogram tingkat kesukaan terhadap kenampakan ikan kakap merah asin

Figure 5. Preferences based on appearance at salted fish red snapper.

Tabel 4. Hasil analisis sidik ragam nilai organoleptik kenampakan ikan kakap merah asin.

Table 4. Anova of organoleptic value on pxeferences at salted fish red snapper.

\begin{tabular}{|c|c|c|c|}
\hline $\begin{array}{c}\text { Sumber } \\
\text { keragaman }\end{array}$ & db JK & & $\begin{array}{c}F_{\text {tabel }} \\
\mathbf{0 , 0 5 0 , 0 1}\end{array}$ \\
\hline Perlakuan & 8721,61 & (4) $1,01^{* *}$ & $3,235,47$ \\
\hline A & 0,82 & $2,23^{\mathrm{tn}}$ & $4,268,02$ \\
\hline B & 3,49 & $9,51^{* *}$ & $4,268,02$ \\
\hline AB (interaksi) & $4,717,29$ & $79,32976,15^{* *}$ & $3,636,42$ \\
\hline Galat & 1.65 & 0,18 & \\
\hline Total & 17723,26 & & \\
\hline
\end{tabular}

Dari Tabel 4, dapat dilihat bahwa perlakuan konsentrasilarutan garam (A) tidak memberikan pengaruh yang nyata, sedangkan pada perlakuan tama pengeringan (B) memberikan pengaruh yang sangat nyata. Sementara interaksi kedua perlakuan memberikan pengaruh yang sangat nyata, ini berarti ada pengaruh konsentrasi larutan garam dan lama pengeringan terhadap nilai organoleptik kenampakan ikan kakap merah asin. Dari uji BNT menunjukkan bahwa perlakuan lama pengeringan rata-rata memberikan pengaruh yang sangat berbeda nyata dan berbeda nyata. Interaksi antara kedua perlakuan umumnya memberikan hasil yang sangat berbeda nyata dan berbeda nyata, kecuali pada interaksi berikut ini yang tidak nyata perbedaannya. Pada lama pengeringan 12 jam dengan nilai kenampakan pada konsentrasi larutan garam $13 \%, 15 \%$ dan $17 \%$, juga pada konsentrasi $17 \%$ pengeringan $10 \mathrm{jam}$.

- Konsentrasi $15 \%$ pengeringan 12 jam dengan konsentrasi $13 \%$ pengeringan 12 jam dan konsentrasi $17 \%$ pengeringan $10 \mathrm{jam}$.

- Konsentrasi $17 \%$ pengeringan 10 jam dengan konsentrasi $15 \%$ pengeringan 10 jam dan konsentrasi $13 \%$ pengeringan $12 \mathrm{jam}$.

- Konsentrasi $13 \%$ pengeringan 12 jam dengan konsentrasi $15 \%$ pengeringan 10 jam.

- Pengeringan 10 jam dengan niłai kenampakan pada konsentrasi $13 \%$ dan $15 \%$. juga pada konsentrasi $17 \%$ pengeringan 8 jam.

- Pengeringan 8 jam dengan hilai kenampakan pada konsentrasi $15 \%$ dan $7 \%$, juga pada konsentrasi $13 \%$ pengeringan $10 \mathrm{jam}$.

- Konsentrasi 13\% pengeringan 10 jam dengan konsentrasi $15 \%$ pengeringan 8 jam.

- Pengeringan \& jam dengan nilai kenampakan pada konsentrasi $13 \%$ dan $15 \%$.

Bąa

Data analisis tingkat kesukaan bau ikan kakap,merah asin yang diperoleh dari hasil penelitran ini dapat dilihat bahwa skor rata-rata tingkat kesukaan bau yang terendah adalah 5,6 (bau tambahan mengganggu, tidak busuk, agak tengik) yaitu pada perlakuan dengan konsentrasi larutan garam 13\% dan lama pengeringan 8 jam. Sedangkan skor rata-rata tingkat kesukaan bau yang tertinggi adalah 8,33 (kurang harum, tanpa bau tambahan) yaitu pada perlakuan dengan konsentrasi larutan garam $17 \%$ dan lama pengeringan 12 jam. Skor rata-rata tingkat kesukaan bau ikan asin ini dari berbagai kombinasi perlakuan dapat dilihat pada Gambar 6.

Kualitas ikan asin kering yang ditetapkan menurut SNI yaitu memiliki skor rata-rata nilai organoleptik 6,5 (Anonimous, 1992). Ini berarti bahwa produk ikan kakap merah asin yang dihasilkan dari masing-masing kombinasi perlakuan umumnya memiliki nilai organoleptik bau yang dapat diterima atau disukai. Penilaian organoleptik untuk bau ikan kakap merah asin dengan skor tertinggi $(8,6)$ lebih disukai panelis karena memiliki bau khas ikan asin, bau garam dan tidak ada bau tengik. Sedangkan penilaian organoleptik untuk bau ikan kakap merah dengan skor terendah $(5,6)$ agak tidak disukai karena bau khas ikan asin dan bau garam tidak terdeteksi melainkan bau tengik. Dengan demikian nilai organoleptik bau meningkat 
dengan adanya penambahan konsentrasi larutan garam, karena garam berfungsi menghambat pertumbuhan mikroba dan mencegah terjadinya perombakan daging ikan, sehingga bau tengik akibat perombakan tersebut dapat dikurangi. Winarno, et al. (1982) menyatakan bahwa mikroba menghasilkan enzim yang dapat menghidrolisa lemak mengakibatkan terjadinya ketengikan atau merusak protein yang menghasilkan bau busuk.

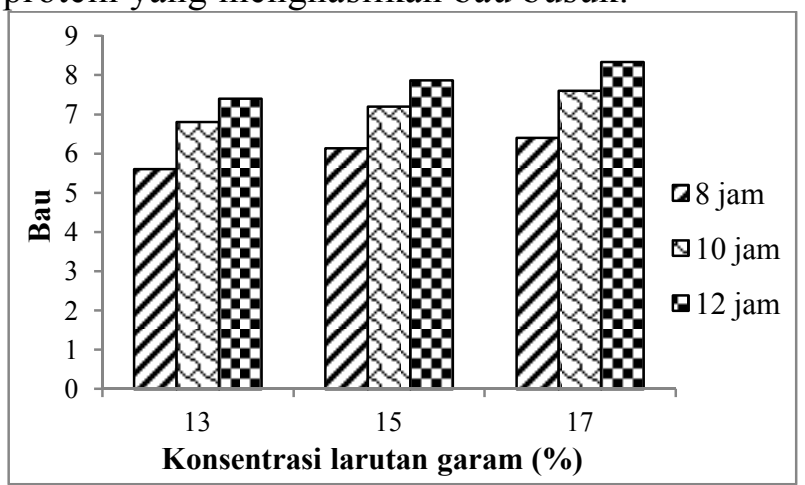

Gambar 6. Tingkat kesukaan terhadap bau ikan kakap merah asin.

Figure 6. Levels of odor preferences at salted fish red snapper.

Tabel 5. Hasil analisis sidik ragam nilai organoleptik bau ikan kakap merah asin.

Table 5. Anova of organoleptic value on odor at salted fish red snapper.

\begin{tabular}{|c|c|c|c|c|c|}
\hline $\begin{array}{c}\text { Sumber } \\
\text { keragaman }\end{array}$ & db & JK & KT & $F_{\text {hitung }}$ & $\begin{array}{c}F_{\text {tabel }} \\
0,050,01\end{array}$ \\
\hline Perlakuan & & 80,89 & 85,11 & $541,99^{*}$ & $3,23,5,47$ \\
\hline A & 2 & 0,54 & 0,27 & $1,709^{\operatorname{tn}}$ & $4,268,02$ \\
\hline B & 2 & 2,55 & 1,28 & $8,119^{*}$ & $4,268,02$ \\
\hline AB (interaksi) & & 77,81 & 169,45 & & $3,636,42$ \\
\hline Galat & 9 & 1,41 & 0,16 & & \\
\hline Total & 17 & 82,31 & & $y$ & \\
\hline
\end{tabular}

Dari Tabel 5, dapat dilikat bahwa perlakuan konsentrasi larutan garam (A) tidak memberikan pengaruh yang nyata, sedangkan perlakuan lama pengeringan dan interaksi memberikan pengaruh yang sapgat nyata, ini berarti ada pengaruh konsentrasi larutan garam dan lama pengeringan terhadap milai organoleptik bau ikan kakap merah asing sehingga perlu dilakukan uji lanjut untuk mengetahui perlakuan-perlakuan mana saja yang berbeda nyata.

Dari tabel uji BNT menunjukkan bahwa perbedaan lama pengeringan memberikan pengaruh yang sangat nyata dan berbeda nyata. Interaksi kedua perlakuan memberikan hasil yang sangat nyata dan berbeda nyata kecuali pada interaksi berikut ini yang tidak nyata perbedaannya.

- Pada lama pengeringan 12 jam dengan nilai kenampakan pada konsentrasi larutan garam 15\% dan $17 \%$, juga pada konsentrasi $17 \%$ pengeringan 10 jam.

- Pengeringan 12 jam dengan nilai kenampakan pada konsentrasi larutan garam 13\% dan $15 \%$, juga pada pengeringan 10 jam pada nilai kenampakan pada konsentrasi larutan garam 15\% dan $17 \%$.

- Pengeringan 10 jam dengan nilai kenampakan pada konsentrasi larutan garam 13\%, 15\%, dan $17 \%$, juga pada konsentrasi $13 \%$ pengeringan $12 \mathrm{jam}$.

- Konsentrasi $13 \%$ pengeringan 12 jan dan konsentrasi $13 \%$ pengeringan 10 jam đengan konsentrasi $15 \%$ pengeringan 10 jam.

- Konsentrasi 17\% pengeringan 8jam dengan konsentrasi $15 \%$ pengeringan 10 jam dan konsentrasi $13 \%$ pengeringan 10 jam.

- Pengeringan 8 jam dengan nilai kenampakan pada konsentrasi lanutan garam $15 \%$ dan $17 \%$, juga pada konsentrasi $13 \%$ pengeringan 10 jam.

- Pengeringan 8 jam dengan nilai kenampakan pada konsentrasi larutan garam $13 \%$ dan $17 \%$ juga pâda konsentrasi $15 \%$ dan $17 \%$.

- Pengeringan 8 jam dengan nilai kenampakan padakonsentrasi larutan garam 13\% dan 15\%.

\section{Cita Rasa}

Data analisis tingkat kesukaan cita rasa ikan kakap merah yang diperoleh dari hasil penelitian ini dapat dilihat bahwa skor rata-rata tingkat kesukaan cita rasa yang terendah adalah 5,8 (agak enak, spesifik jenis, sedikit rasa tambahan mendekati enak) yaitu pada perlakuan konsentrasi larutan garam 13\% dengan lama pengeringan 8 jam. Sedangkan skor rata-rata tingkat kesukaan cita rasa yang tertinggi adalah 8,2 (sangat enak sekali, spesifik jenis, tanpa rasa tambahan) yaitu pada perlakuan konsentrasi larutan garam 15\% dan lama pengeringan $12 \mathrm{jam}$. Skor rata-rata tingkat kesukaan cita rasa ikan kakap merah asin dari berbagai kombinasi perlakuan dapat dilihat pada Gambar 7 .

Kualitas ikan asin kering yang ditetapkan menurut SNI yaitu memiliki skor rata-rata nilai organoleptik 6,5 (Anonimous, 1992). Ini berarti bahwa produk ikan kakap merah asin yang dihasilkan dari setiap kombinasi perlakuan umumnya memiliki nilai organoleptik cita rasa yang dapat diterima atau disukai. Penilaian organoleptik untuk cita rasa ikan kakap merah asin dengan skor tertinggi $(8,2)$ lebih disukai panelis karena memiliki cita rasa yang enak, spesifik, rasa asin yang cukup. Sedangkan penilaian organoleptik untuk rasa ikan kakap merah asin dengan skor terendah $(5,8)$ agak tak disukai panelis karena rasa yang agak tidak 
enak, biasa. Adanya perbedaan kesukaan cita rasa pada produk ikan kakap merah asin dari berbagai kombinasi perlakuan, karena adanya penambahan konsentrasi larutan garam. Dengan demikian nilai organoleptik cita rasa meningkat dengan adanya penambahan garam, karena garam selain membantu mengawetkan juga memberikan cita rasa yang khas yaitu rasa asin. Moeljanto (1982) menyatakan bahwa dengan penggaraman didapat keuntungan yaitu daging ikan lebih kokoh karena terjadi penarikan air oleh garam dan pengumpalan protein serta menyebabkan cita rasa ikan menjadi lebih enak.

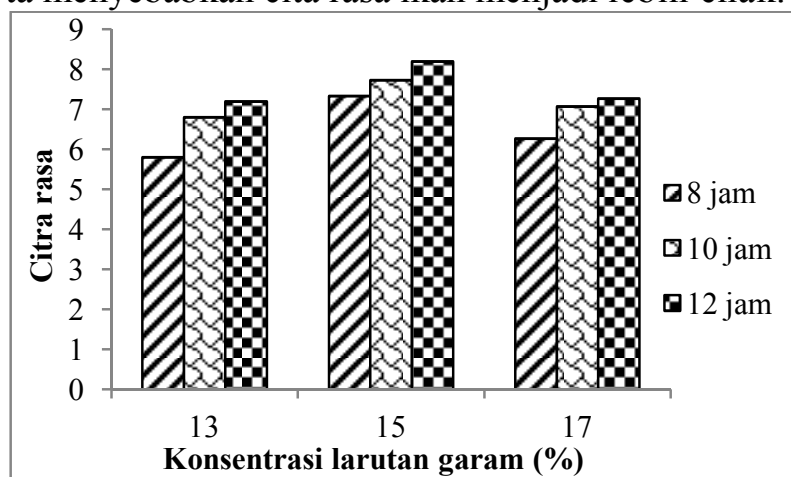

Gambar 7. Tingkat kesukaan terhadap cita rasa ikan kakap merah asin

Figure 7. Preferences levels of flavor at salted fish red snapper.

Tabel 6. Hasil analisis sidik ragam nilai organoleptik cita rasa ikan kakap merah asin.

Table 6. Anova of organoleptic value on flayov at salted fish red snapper.



Pada Tabel 6 dapat dilihat bahwa perlakuan konsentrasil larutan garam (A) dan lama pengeringan (B) tidak memberikan pengaruh yang nyata, sedangkan interaksi kedua perlakuan memberikan pengaruh yang sangat nyata. Ini berarti ada pengaruh kdnsentrasi larutan garam dan lama pengeringan terhadap nilai organoleptik cita rasa ikan kakap merah asin, sehingga perlu dilakukan uji lanjut untuk mengetahui perlakuan-perlakuan mana saja yang berbeda nyata. Dari uji BNT menunjukkan interaksi kedua perlakuan tidak memberikan pengaruh nyata, kecuali pada interaksi berikut ini yang nyata perbedaannya.

- Konsentrasi larutan garam 15\% lama pengeringan 12 jam dengan konsentrasi 13\% penge- ringan 8 jam dan konsentrasi 17\% pengeringan 8 jam sangat berbeda nyata dan juga konsentrasi $13 \%$ pengeringan 10 jam dan konsentrasi $17 \%$ pengeringan 10 jam berbeda nyata.

- Konsentrasi $15 \%$ pengeringan 10 jam dengan konsentrasi $13 \%$ pengeringan 8 jam sangat berbeda nyata dan juga konsentrasi $17 \%$ pengeringan 8 jam berbeda nyata.

- Konsentrasi $15 \%$ pengeringan 8 jam dengan konsentrasi $13 \%$ pengeringan 8 jam dankonsentrasi $17 \%$ pengeringan 8 jam berbeda nyata.

- Konsentrasi $17 \%$ pengeringan 12 jam dengan konsentrasi $13 \%$ pengeringan 8 \% nyata.

- Konsentrasi $13 \%$ pengeringan 12 jam dengan konsentrasi $13 \%$ pengeringan 8 jam berbeda nyata.

- Konsentrasi 17\% pengerngan 10 jam dengan konsentrasi $13 \%$ pengeringan 8 jam berbeda nyata.

\section{Konsistensi}

Analisis tingkat kesukaan konsistensi ikan kakap meraba asin yang diperoleh dapat dilihat bahwa skôr rata-rata tingkat kesukaan konsistensi yang terendah adalah 5,87 (lunak, basah, tidak mudah terutai mengarah padat) yaitu pada perlakuan konsentrasi larutan garam 13\% dan lama pengeringan 8 jam. Sedangkan skor rata-rata tingkat kesukaan konsistensi tertinggi adalah 8,6 (terlalu keras, tidak rapuh mengarah padat, kompak) yaitu pada perlakuan konsentrasi larutan garam 17\% dan lama pengeringan 12 jam. Skor rata-rata tingkat kesukaan konsistensi ikan kakap merah asin dari berbagai kombinasi perlakuan dapat dilihat pada Gambar 8.



Gambar 8. Tingkat kesukaan terhadap konsistensi ikan kakap merah asin.

Figure 8. Preferences levels of consistency at salted fish red snapper.

Kualitas ikan asin kering yang ditetapkan menurut SNI yaitu memiliki skor rata-rata nilai organoleptik 6,5 (Anonimous, 1992). Ini berarti bahwa produk ikan kakap merah asin yang dihasilkan 
dari setiap kombinasi perlakuan umumnya nilai organoleptik konsistensi dapat diterima atau disukai. Penilaian organoleptik untuk konsistensi produk ikan kakap merah asin dengan skor tertinggi $(8,6)$ lebih disukai panelis karena memiliki konsistensi bagus, padat sesuai konsistensi ikan asin kering, tidak basah dan lunak. Sedangkan penilaian organoleptik untuk konsistensi ikan kakap merah asin dengan skor terendah $(5,87)$ agak tak disukai panelis karena konsistensi lunak dan basah. Dengan demikian maka semakin tinggi konsentrasi larutan garam nilai konsistensi makin baik yang mungkin dipengaruhi oleh kekompakan daging dan menurunnya kadar air. Buckle at al. (1987) menyatakan bahwa bila garam memasuki jaringan otot, konsistensi menjadi lebih lekat.

Tabel 7. Hasil analisis sidik ragam nilai organoleptik konsistensi ikan kakap merah asin

Table 7. Anova of organoleptic values on consistency at salted fish red snapper.

\begin{tabular}{|c|c|c|c|c|c|}
\hline $\begin{array}{c}\text { Sumber } \\
\text { Keragaman }\end{array}$ & db & JK & KT & $\mathbf{F}_{\text {hitung }}$ & $\begin{array}{c}\mathbf{F}_{\text {tabel }} \\
\mathbf{0 , 0 5 0 , 0 1}\end{array}$ \\
\hline Perlakuan & & 716,22 & 89,53 & $444,34^{* *}$ & $3,23 \quad 5,47$ \\
\hline A & 2 & 1,13 & 0,56 & $2,79^{\text {tn }}$ & $4,268,02$ \\
\hline B & 2 & 1,09 & 0,54 & $2,70^{\operatorname{tn}}$ & $4,268,02$ \\
\hline AB (interaksi) & 4 & 714,00 & 178,50 & $885,94^{* *}$ & $3,63 \quad 6,42$ \\
\hline Galat & 9 & 1,81 & 0,20 & & \\
\hline Total & 17 & 718,03 & & & \\
\hline
\end{tabular}

Seperti pada uji organoleptik cita rasa, uji organoleptik konsistensi berdasarkan hasil sidik ragam menunjukkan bahwa perlakuan dengarp penggunaan konsentrasi larutan garam yang berbeda dan perlakuan pengeringan dengân waktu yang berbeda tidak memberikan pengarnh yang nyata, sedangkan interaksi dari kedua perlakuan memberikan pengaruh yang sangat nyata terhadap nilai konsistensi ikan kakap merah asin, sehingga dilakukan uji lanjut unture méngetahui perlakuan mana saja yang berbedanyata. Sama halnya dengan cita rasa, uji BNT pada nilai konsistensi hanya dilakukan pada interaksi dari kedua perlakuan diketahui bahwa sebagtan besar nilai cita rasa pada interaksi keduatperlakuan memberikan hasil yang tidak nyata, kecuali pada interaksi berikut ini yang nyata perbedaannya.

- Konsentrasi larutan garam 15\%, lama pengeringan 8 jam dengan konsentrasi $13 \%$ pengeringan 8 jam, konsentrasi $13 \%$ pengeringan 10 jam dan konsentrasi $15 \%$ pengeringan 8 jam sangat berbeda nyata dan juga konsentrasi $13 \%$ pengeringan $12 \mathrm{jam}$, konsentrasi $17 \%$ pengeringan 8 jam dan konsentrasi $15 \%$ pengeringan 10 jam berbeda nyata.
- Konsentrasi 13\% pengeringan 12 jam dengan konsentrasi $13 \%$ pengeringan 8 jam sangat berbeda nyata dan konsentrasi $13 \%$ pengeringan 10 jam berbeda nyata.

- Konsentrasi $17 \%$ pengeringan 10 jam dengan konsentrasi $13 \%$ pengeringan 8 jam berbeda nyata.

- Konsentrasi $15 \%$ pengeringan 10 jam dengan konsentrasi $13 \%$ pengeringan 8 jam berbeda nyata.

- Konsentrasi 17\% pengeringan 8 jam dengan konsentrasi $13 \%$ pengeringan 8 jarn berbéda nyata.

- Konsentrasi $13 \%$ pengeringan 12 jam dengan konsentrasi $13 \%$ pengeringan 8 jam berbeda nyata.

\section{KESIMPULAN}

Berdasarkan hasil penelitian, maka dapat ditarik kesimpulan sebagai berikut:

Dari andtisis kadar air, produk ikan kakap merah pada kønsentrasi larutan garam 15\% dengan lama pengeringan 12 jam yaitu $37,38 \%$ juga pada konsentrasil larutan garam 17\% dengan lama pengeringan 12 jam yaitu $33,71 \%$ memiliki nilai kadar air yang dapat diterima dan memiliki mutu yang baik.

Dari analisis kadar lemak, produk ikan pada konsentrasi larutan garam 17\% dengan lama pengeringan 12 jam yaitu $9,17 \%$ memiliki nilai kadar lemak yang dapat diterima dan memiliki mutu yang baik.

Dari analisis kadar protein, produk ikan yang dihasilkan pada konsentrasi larutan garam $15 \%$ dengan lama pengeringan 8 jam yaitu $39,2 \%$ dan konsentrasi larutan garam $17 \%$ dengan lama pengeringan 10 jam yaitu $39,73 \%$ memiliki nilai kadar protein yang dapat diterima dan memiliki mutu yang baik.

Berdasarkan uji organoleptik pada produk ikan yang paling disukai terdapat pada produk dengan konsentrasi larutan garam 15\% hingga 17\% dengan lama pengeringan $12 \mathrm{jam}$.

\section{DAFTAR PUSTAKA}

Adawyah R. 2008. Pengolahan dan pengawetan ikan. Ed. 1. Bumi Aksara. Jakarta. 160 hal.

Afrianto E dan Liviawati E. 1989. Pengawetan dan pengolahan ikan. Kanisius. Yokyakarta.

Anonimous. 1992. Standar Nasional Indonesia (SNI) ikan asin kering, kumpulan standar metode pengujian mutu hasil perikanan. Jakarta.

2003. Teknologi pengolahan ikan di Indonesia, kerja sama Diktorat Mutu dan Pengolahan Hasil Peri- 
kanan. Diktorat Jendaral Perikanan Tangkap dan Japan Internasional Corporation Agency (JICA).

Buckle KA, Edwards RA, Flegi FH, Wolton M. 1987. Ilmu pangan. UI-Press. Jakarta.

Juliana. 1999. Pengaruh suhu pengeringan terhadap mutu ikan tepung siput laut (Littoraria scabra). Fakultas Perikanan dan Ilmu Kelautan. UNSRAT. Manado.

Mardalis. 1989. Metode penelitian. PT. Bumi Aksara. Jakarta.

Moeljanto R. 1982. Penggaraman dan pengeringan ikan. PT. Penebar Swadaya. Jakarta.

1992. Pengawetan dan Pengolahan Hasil Perikanan. PT. Penebar Swadaya. Jakarta.

Muthadi T dan Ayustaningwarno F. 2010. Teknologi Proses Pengolahan Pangan. Alfabeta. Bandung. 246 hal.
Sudarmadji SB, Haryono dan Suhardi. 1997. Analisis bahan makanan dan pertanian. Liberty. Yogyakarta.

Suwetja IK. 2011. Biokomia hasil perikanan. Prima Aksara. Jakarta. 204 hal.

Suwetja IK. 2013. Indeks mutu kesegatan ikan. Bayumedia Publ. Malang. 88 hal.

Soekarto S. 1991. Penilaian organoleptik untuk industri pangan dan hasil pertanian. IPB. Bogor.

Steel RGD and Torrie JH. 1998. Principles and Procedures of statistics. McGrew hill book company. New York. $481 \mathrm{p}$.

Winarno FG, Fardiaz S dan Fardiaz D. 1982. Pengantar teknologi pangan. PT. Gramedia. Jakarta.

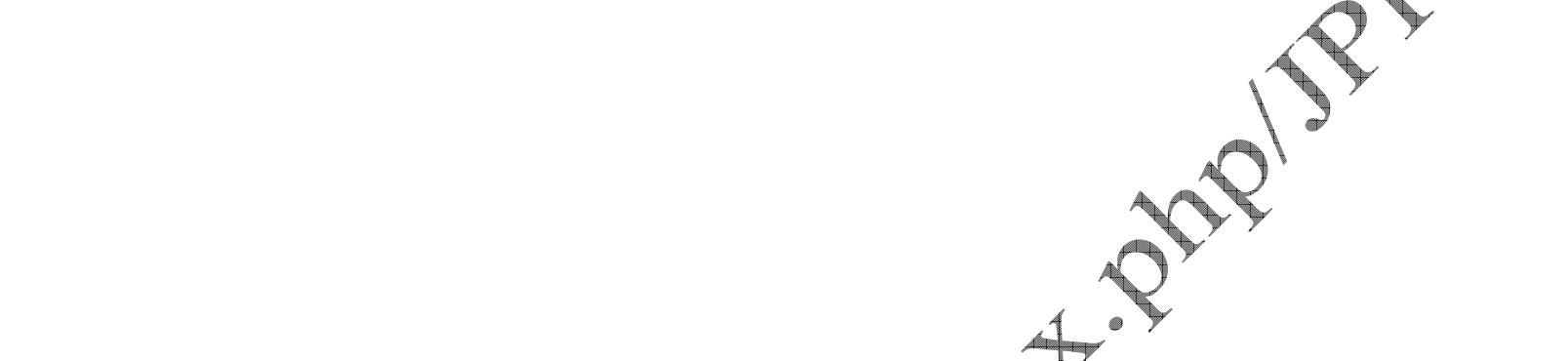

